\title{
An Empirical Analysis of Overtime Greek Regional Development Strategies/Policies the Period 1976-2015: The Case of the Region of Thrace
}

\author{
${ }^{1}$ Dr. E. Stathakis, ${ }^{2}$ E. Stambologlou* \\ ${ }^{1}$ Diploma of Mechanical Engineer P\&A, M.Sc. in Advance Information Systems, a PhD Candidate in \\ Economy of Energy, \\ ${ }^{2}$ Diploma of Surveyor Engineer (NTUA 1980), M.Sc. in System Engineering and management, a PhD \\ candidate in Rural Infrastructures
}

\begin{abstract}
Thrace had and has relatively favor conditions for substantial development, that is, good and adequate physical, environmental and cultural resources, but paradoxically remains the poorest Greek region. What missed were the smart, consistent and effective regional development policies, capable of counterbalancing the disadvantages. Some not well-designed policies, based on generous financial incentives after 1976, contributed very little to its growth because they were fragmentary without focus and cohesion. They supported a shallow growth, unable to create a good/stable and sustainable basis for cost, quality and functional competitive advantages. Our empirical research proves well- documented the insufficiency of regional policies followed the last 40 years, 1976-2015. In this context, we suggest some indicative new regional policies that will have to be based on both, in smart incentives, supporting smart/flexible specialization well-branded globally and in intelligent production systems capable of supporting effectively, either outsourcing production via long term cooperation, or domestic production for niche markets.
\end{abstract}

Keywords: Regional development, regional competitive advantages, innovative regional strategies, policies

\section{Introduction}

The literature perceives regional economic and productive systems as key-drivers of spatial economic convergence and growth into the context of endogenous evolutionary development processes. Globalization in general, has two basic effects, firstly huge MNE's to invest directly wherever find cost-effective conditions to gain cost-competitive advantages and second the same MNE's to look for regions with smart competitive advantages and local production specification. E.g., geography should partially be lost its importance as a criterion for production plants, but for some production activities and functions, the spatial dimension remains important for global competitiveness. So, regions, or areas offering some special comparative and competitive advantages can attract more and better quality of Foreign Direct Investments (FDI's).

Of course, various determinants are influencing the global attractiveness and decision-makers/takers to choose the best area to invest. The quality of human resources, the intelligent infrastructure and the degree of utilization of local resources through intelligent and flexible production processes, acquire a key role in regional development, employment growth and competitiveness. Equally significant is the development of state policies contributing to, regional cohesion, FDI's attracting, cost-effective, innovative, fair and adaptable to the relevant international conditions business environment (Akalpler and Adil 2017, OECD 2019).

The new regional growth models signal the gradual abandonment of obsolete spatial growth policies, based mainly on the transfer of great state resources to poorer regions without a cohesive strategy and to special investment incentives, aiming to create artificial development poles to be attracted valuable FDI's (Lamprianidis 1989, 2008, McKiernan 1992, Stathakis 2013). 
There are many theories regarding regional development covering almost every growth matter, but we chose only three (3) among them, considering them as the most representative and relative to our work. These three theories support three different regional development models, with differences based on assumptions regarding constant and increasing returns to scale of total investments, the quality dimension of some growth determinants and the contribution of certain technological infrastructure to quantity, quality and competitiveness of growth. Furthermore, the previous theories seem to interpret better the causes for the today bad economic situation of the Greek poorest region of Thrace (Stathakis 2013 and Stathakis and Bandekas 2018).

The first, developed by Lucas (1988) who claims that the quality of human capital is the key factor in the competitive production systems. The basic prerequisites for development, according to Lucas (1988), are the great investments in human capital. The competitive production systems present constant returns to scale, e.g., high profitability of their every economic unit. It means that already richer countries, or regions, are capable of investing more money in people than poorer countries, or regions. In other words, there is a direct correlation between the quality of human capital and growth rates and poorer countries, or regions have to invest the few resources initially to upgrade manpower and later to technical infrastructure.

The second, developed by Romer (1990) who argues that the accumulation of applied knowledge and technologies in an area play the most important role in the development process. New applied knowledge and technologies come from $R \& D$ activities that produce innovations, which in turn, disseminated them to the rest of the economic fields, causes new development, and so on. Almost similar views claimed by Hurst et al. (2000), in a working paper regarding the essential factors of spatial development.

The spatial production systems present based on knowledge, technologies, R\&D activities and innovations attract new investors in such high-tech industries, new growth waves, and so on. Regions having greater knowledge stock are in a better position than others and thus can develop faster. Somewhat similar views claimed later, 1998, Knorringa and Meyer-Starmer (1998) giving a wider dimension on regional planning and development, stressing the role of regional business alliances and cooperation.

The third, called new economic geography, developed by Krugman (1998), who contributed the best to the research what causes the spatial divergences, or convergences/inequalities among countries, or regions. This approach differs from the two previous, since it analyzes the concept of regional inequalities, introducing new theoretical and empirical growth tools such as the size of markets, the accumulation of capital, the level of technology, the transport/logistics costs and the outcome functional economies of scale. He argues that economic activities, on a spatial basis, tend to be concentrated in certain already privileged countries, or regions. In this sense, he created the model of pioneered regions which can be met in many countries having different growth level. For instance, in Greece, the developing gap between regions of Attica and Thrace is huge, since Thrace has Gross Domestic Product (GDP)/capita equals to 49,5\% of Attica.

Focusing on their views regarding which are the fundamental determinants for fast, sustainable and continuous spatial growth, we note that, all consider the industry as the most stable and powerful growth determinant. Since the industrial sector, mainly the innovative, seems to be the key spatial development factor, therefore, there is a close correlation between regional developmental policies/strategies and kind of industrial ones, a question is emerged to everyone, what means "good regional growth strategy" for a poor region and which development tools, experiences and examples will have to be implemented. The answer is yes since the global economic history proves it very clear. A suitable regional growth strategy will have to answer to questions, such as, what special and differentiated the region offers, what are the characteristics, or functions of the region that can attract good and specific investments, what are the investment disincentives, what is the present situation of foreign and domestic direct investments, which is the expected economic situation about attracting FDI's, what investments are desirable for the area and what and how much is the demand for FDI's, in the region (Cortright 2001, Todtling and Trippl 2005, Tampakoudis et al. 2017)

Ever, an intelligent industrial strategy will have to be designed very carefully, having features of a flexible and smart strategy, based on knowledge innovation and new technologies able to contribute the best to the competitive and sustainable development of a region (Wessner 2005 and Yu and Jackson 2011 and Rehman 2016). This is well-documented if we look at more developed countries, USA, Germany, Japan, etc. and 
study the certain national and regional advanced industrial strategies followed by them (Cooke and Morgan 1998, Cooke 2001). Of course, in productive spatial systems, the introduction of innovations to every sector and process phase is the basic precondition for fast, high global competitiveness and continuous growth. All the economic growth theories, classical, neoclassical, kensyanes, neokensyanes, referred to, directly or indirectly, to the great contribution of the intelligent and flexible industrial strategies to strong spatial growth in quantitative and qualitative basis (Krugman and Venables 1995, Esteban 2000). How all the regional development theories applied in Thrace will be examined to the next.

\section{Regional policies and strategies followed overtime in Thrace}

Despite Greek authorities, after 1976, decided to carry out for Thrace some ad-hoc special regional policies, based mainly on generous incentives, aiming to attract serious direct investments, they failed because of their low effectiveness and focus. They proved unable to counterbalance four great disadvantages, its population qualitative insufficiency and heterogeneity, the sense of a historical threat from neighbors, the complete lack of investments until 1975 and its geographic isolation until 1990. After 1990, some of the disadvantages disappeared, but the new wave of economic/production globalization created some others. Empirical research found out that, regions like Thrace, need something excellent and different of business as usual growth policies, for fast growth. It is only the smart growth, based on strong competitive production systems, mainly industrial, capable of ensuring a prominent position in the international markets. To the next, and before we present the overtime regional growth policies, criticizing them and focusing on their ineffectiveness, we considered useful to interview some crucial decision-makers. So that, to shape a better picture regarding overtime regional development policies, we used Delphi method interviewing 12 decision-makers belonging to every socioeconomic field. The 12 decision-makers, along with our findings, helped us to argue that the sustainable and competitive development of a region, seems to be affected over time by nine (9) key-factors (Stathakis 2013).

\section{Table 1: the nine key factors affecting the regional development}

\begin{tabular}{|l|l|}
\hline Key-factors affecting regional development & $\begin{array}{l}\text { Weighted } \\
\text { index \% }\end{array}$ \\
\hline Human Resources quality, specialization, education level, etc. & 28 \\
\hline $\begin{array}{l}\text { Quality/quantity of technical, social, technological, energy and research } \\
\text { infrastructures }\end{array}$ & 21 \\
\hline $\begin{array}{l}\text { Sectoral, products structure of economy and competitiveness of the production } \\
\text { systems }\end{array}$ & 14 \\
\hline $\begin{array}{l}\text { Degree of cooperation, networking, integrations and synergies of the regional } \\
\text { production systems with universities and other research centers }\end{array}$ & 12 \\
\hline Quality of educational institutions, on a comparable basis, national, international & 10 \\
\hline The geostrategic position of the region in the wider geographical area & 5 \\
\hline Population size, and therefore the market size & 4 \\
\hline Quality of the natural environment & 3 \\
\hline Existence quantitative exploitable precious natural resources & 3 \\
\hline
\end{tabular}

\section{Source: Stathakis (2013), a compilation by authors}

The above table should help, in practice, Thracian policymakers to redesign their policies and strategies for regional development to be more intelligent, smart, flexible, cost-effective, and sustainable. To the next, it will be described in time basis the followed regional policies and strategies in Thrace. Until 1975 there is not any regional policy in Greece since the basic problem was the underdevelopment of the whole country. Essentially regional policies and strategies carried out for first time in Greece in 1976 for the region of Thrace. Initially, they were very simple because there is no experience and resources for them were very few. They were improved gradually and reached their peak between 1985-1995 (Stathakis 2013). They expressed through strong incentives with clear geographical differentiation for Thrace but unfortunately lacked sectoral 
expertise and orientation. They have during the period 1976-1995, 2 basic goals, to attract new private investors and the state to invest much more capital in new technical and social infrastructures than to other regions. Policymakers for a specific and effective regional strategy for the poorest region of Greece wished simply to attract many direct investments through the strong incentives, without a certain and focused mission, vision, and goals. Until 1976, the total and mainly the industrial production system of Thrace was primitive, uncompetitive, introversive and localized.

The next period 1976-1995, the state resources spent/invested for private and public investments, aiming to faster development of Thrace, were sufficient quantitatively and ineffective qualitatively. After 1997, when a new globalization wave emerged, due to the collapse of communism, the competition was intensified to every market. The undeveloped Thrace faced new challenges, decreased exports, intense deindustrialization, since a great number of manufacturing unit's closed-70\% within 15 years and about 25.000 permanent jobs lost, decreased incomes leading to smaller demand, etc.

There are many causes and justifications for that. First, after 1996, the regional growth policy changed dramatically, the new development laws had smaller spatial differentiation and incentives, so the artificial cost competitive advantages due to strong and Adhoc incentives mentioned to previous for private investors were eliminated. Second, the fall of the Eastern European Block changed the investment and business environment and the destination of FDI's dramatically.

The former E.E countries with comparatively low nominal and real labor cost that was reflected in the productivity/unit cost attracted a lot of FDI's in their all forms, from relocation, entirely new plants to mergers and acquisitions. Thus, the crisis of deindustrialization of Thrace, that borders with such countries, took large dimensions. This firms' relocation phenomenon affected particularly labor-intensive sectors and generally but less the total traditional manufacturing system that is dominated in Thrace. It is noted the great majority of production units, about $67,3 \%$, belong to such sectors, producing middle and low to medium-tech products at uncompetitive cost (Jackson and Petrakos 2001, Carmona et al. 2009).

In the period 1997-2009, the regional growth and industrial strategies followed were without realistic focusing, leading to the most, to production units belonging to 5 traditional industries, food/beverages, textiles, ready-made clothes, aluminum products, having medium to small size, without the mandatory introduction of modern technology, automation and management tools.

After 2009, the huge economic crisis has deteriorated the economic situation and unemployment launched to 27, 5\%. In conclusion, developmental delay and inefficiency, expressed in Thrace in 5 ways:

1. With the closure of the majority of every size manufacturing firms, large size $98 \%$, medium size $87 \%$, small and very small size 66\%. It happened, after 1988, because of the generous export subsidies stopped and after 1992, due to intense global competition. An average 12,6\% of them exploited 25$49 \%$ of their real capacity, and only an average $7,8 \%$ exploited $50-100 \%$ of their real capacity.

2. With the significant loss of jobs, about $76.5 \%$ of them were lost. The $67,7 \%$ were lost due to closure of manufacturing firms, and the rest $32,3 \%$ due to job-cuts/downsizing of the firms remaining in operation.

3. With whatever investment activities decreased, the decreasing was about $65,2 \%$ for the period 1998 2007 and 87,6\% between 2009-2014, despite some generous investment incentives continue to have existed.

4. With the relocation of $95,6 \%$ of labor-intensive manufacturing firms. They chose as relocation area the Balkans, mainly Bulgaria.

5. With the significant reducing of the contribution of the secondary sector to regional GDP, gross added value and employment. The real contribution was decreased at $72,4 \%$ to the GDP, 65,4 to Gross Added Value (GAV) and 94,6\% to total employment.

All these had a probably dramatic impact on the evolution of the development rate of Thrace, expressed in quantitative and qualitative changes of GDP and employment. Table 2 presents some developmental and structural data/information of GDP, on the weighted price of the year 2005 (Mourmouris 1997, Polyzos 1997, HELSTAT 1985-2014) 
Table 2: Structure and development over time of Thracian GDP

\begin{tabular}{|l|l|l|l|}
\hline Sector/Period & $\mathbf{1 9 9 6}$ & $\mathbf{2 0 0 8}$ & $\mathbf{2 0 1 2}$ \\
\hline GDP in mil $€$ & 3.535 & 4.203 & 3.152 \\
\hline Primary \% & 16,9 & 12,4 & 14,2 \\
\hline Secondary \% & 19,8 & 15,6 & 9,4 \\
\hline Tertiary \% & 63,3 & 72,0 & 76,4 \\
\hline
\end{tabular}

Source: Hellenic Statistical Authority (ELSTAT): We have adapted data, e.g., they are deflated. Also, calculates without Drama, Kavala, as spatial units of Region of Eastern Macedonia and Thrace (REMTH) - compilation by authors

After 2010, Thrace tends to diverge in developmental terms, by $12 \%$, regarding the average growth rate of the country. Its GDP was reduced by $37 \%$ compared to the average $25 \%$ of the country. As many experts argue, regional disparities follow the economic cycles. They increased during the growth period and fell during the recession. And even, in poor regions, with specific territorial competitive disadvantages, such as Thrace, take place more significant decreases in their GDP (HELSTAT 1985-2014).

In the period 1996-2013, the overall reduction in the number of comparatively remarkable manufacturing enterprises is estimated at 708 units, e.g., a decrease of $85 \%$ of total ones. The most affected industries are textiles, clothing, wood, furniture, metallurgy, and metal products. The bordering Turkey, with its exports and cross-border trade, pushed mainly the industries of textile, clothing, wood and furniture. If they add up, the jobs lost by the firms that completely stopped to operate, 12.184 , the jobs that were lost, during the same period, by firms operating with due less production capacity, 2.985 and the jobs that were dropped by the closure of small firms, 2.432, we come to the painful conclusion that, in the twenty years, from 1996 to 2014, have been lost due to deindustrialization and heavy economic crisis, more than 17,600 permanent jobs in Thrace (Academy of Athens 1994, Stathakis 2013, HELSTAT 1985-2014).

The quantitative statistical data regarding the contribution of development laws and investment incentives in the industrial and overall development of Thrace has a particular interest. While, the quantitative statistical information in sectoral basis, regarding the same issue, is even more unfavorable. In Table 3, they give statistical data and information regarding the contribution of investment incentives in Thrace for the period 1976-2010 (amounts in $€ \mathrm{~m}$, the reference year for prices 2005, also, they are included agricultural and tourism investments).

Table 3: Contribution of development laws in attracting direct investments, domestic and foreign

\begin{tabular}{|l|l|l|l|l|l|}
\hline $\begin{array}{l}\text { Incentives } \\
\text { and } \\
\text { Investment } \\
\text { laws }\end{array}$ & $\begin{array}{l}\text { Number of } \\
\text { investments } \\
\text { submitted }\end{array}$ & $\begin{array}{l}\text { Number of } \\
\text { investments } \\
\text { approved }\end{array}$ & $\begin{array}{l}\text { Investments } \\
\text { amount in } \mathbf{m}\end{array}$ & $\begin{array}{l}\text { Number } \\
\text { subsidies } \\
\text { approved }\end{array}$ & $\begin{array}{l}\text { New } \\
\text { investments } \\
\text { will create } \\
\text { new jobs }\end{array}$ \\
\hline $279 / 76$ & 1.657 & 422 & 346 & 138 & 13.768 \\
\hline $849 / 78$ & 237 & 76 & 34 & & \\
\hline $1262 / 82$ & 10.054 & 929 & 2.282 & 758 & 42.800 \\
\hline $1892 / 90$ & 3.912 & 984 & $2.791,8$ & 1.165 & 15.320 \\
\hline $2601 / 98$ & 1.325 & 398 & 1.534 & 540 & 9.400 \\
\hline $3299 / 04$ & 875 & 205 & 1.087 & 502 & 3.245 \\
\hline $3908 / 11$ & 128 & 45 & 104,2 & 47 & 1.050 \\
\hline Total & 18.068 & $3.059^{*}$ & 8.235 & 3.103 & 85.583 \\
\hline
\end{tabular}

Source: HELSTAT overtime publications: We have adapted data, e.g. they are deflated. Also, calculates have been done without Drama, Kavala, as spatial units of REMTH 
Remark: a. The $51,1 \%$ of investments, subsidized by special developmental laws refer to, modernize, productive expansions and special investments-energy saving, environment protection, etc. of already existed firms, and the $48,9 \%$ refer to entirely new investments. There was a lack of reliable statistical data, regarding how many of the approved investments for subsidizing were implemented within each development law separately, this interesting topic will be commented only in a descriptive way. The whatever data /information has been collected by some regional authorities, SII: Social Insurance Institution (SII), Organizations of Local Authorities (OLA), Commercial and Industrial Chambers (CIC), REMTH, etc. and elaborated/ adapted by us. b. The percentage $\%$ of investors implemented their approved investments for subsidizing, is rather low, and in no case exceeded the $36.5 \%$ of them.

After the first three years of business operation, the generously subsidized firms faced significant problems regarding the domestic or foreign competition. E.g., the artificial cost competitive advantages helped firms to be viable about three years, and after that, they lost the initial competitive momentum. The profitable manufacturing companies generously subsidized by the Greek state did not exceed $32.5 \%$ of total ones.

Taking as a criterion the overall contribution of subsidized manufacturing firms to the growth rate of the Thracian regional economy and the rise of its social welfare, it was rather low about the public resources spent as subsidies. The additional benefits are equal only to $56,2 \%$ of the total social cost. In the period 1976-2010, were invested 3.500.000.000 € funded in common terms by, a 50,8\% from public resources, a $22,3 \%$ from banks as long-term loans and a 26,9 from the private sector to be created, at least, 25.000 permanent and good jobs.

Unfortunately, despite the huge money spent in Thrace, the final results were very few, since today the remaining jobs in subsidized firms do not exceed 6.250, or the $24 \%$ of forecasted ones (all amounts in permanent prices of the year 2005). At the ex-ante evaluations of regional development policies for Thrace, predicted an additional annual GDP at least 50.000.000 €. But, this goal was not achieved and so that this fact can explain and justify the lower GDP/person of Thrace, comparing to the national average one. Thracian GDP/person never exceeded the $84 \%$ of the national average and $61 \%$ of the Eurozone average one (European Commission 2014, HELSTAT 1985-2014)

\section{Statistical data/information for Thracian manufacturing firms subsidized by developmental laws}

This is referred to some sectoral/ structural data like investment mix, productivity, innovativeness, competitiveness, etc. of Thracian manufacturing firms, as they expressed and influenced over time by the financial, investment, tax and operational generous state incentives. No reference that correlates the size of firms and their structural characteristics, because of inaccurate and missing data/information. Composition of direct investment: The structures of direct investments in the manufacturing sector in Thrace, influenced strongly by the generous and very favorable incentives seem in Table 4:

Table 4: Composition of direct and subsidized investments as \% of total ones in certain periods

\begin{tabular}{|l|l|l|l|}
\hline Composition / Time of period & $\begin{array}{l}\mathbf{1 9 7 6 -} \\
\mathbf{1 9 9 6}\end{array}$ & $\begin{array}{l}\mathbf{1 9 9 7 -} \\
\mathbf{2 0 1 1}\end{array}$ & $\begin{array}{l}\text { Weighted } \\
\text { average }\end{array}$ \\
\hline Completely new direct investments & 62.3 & 39,7 & 48,9 \\
\hline $\begin{array}{l}\text { Capacity-expansions, process modernizations, and special } \\
\text { investment in innovations energy saving and environment } \\
\text { production }\end{array}$ & 37,7 & 60,3 & 51,1 \\
\hline $\begin{array}{l}\text { Capacity expansions for already manufactured products-new } \\
\text { production lines }\end{array}$ & 50,2 & 38,7 & 44,0 \\
\hline Expand production capacity for entirely new products & 16,8 & 20,2 & 17,8 \\
\hline $\begin{array}{l}\text { Replacement/renewal of existing production equipment because } \\
\text { of process and cost problems }\end{array}$ & 20,2 & 17,4 & 18,9 \\
\hline Improving the existing production process & 7,3 & 12,1 & 9,8 \\
\hline
\end{tabular}




\begin{tabular}{|l|l|l|l|}
\hline $\begin{array}{l}\text { For energy saving, environmental protection, and improving } \\
\text { security conditions in the production process }\end{array}$ & 3,2 & 6,1 & 5,1 \\
\hline Introduction entirely new and innovative production process & 2,3 & 5,5 & 4,4 \\
\hline $\begin{array}{l}\text { Firms requested support related to integrate projects promoting } \\
\text { innovation }\end{array}$ & 28,7 & 48,2 & 37,8 \\
\hline $\begin{array}{l}\text { Firms supported by local institutions-universities, etc.- for } \\
\text { specific targeted research and patents projects }\end{array}$ & 12,6 & 23,8 & 16,6 \\
\hline $\begin{array}{l}\text { Firms supported by local public organizations for networks and } \\
\text { clusters of excellence }\end{array}$ & 7,5 & 13,8 & 9,5 \\
\hline
\end{tabular}

Source: Adhoc field research of Eastern Macedonia and Thrace Institute of Technology (EMATTECH) 2014/Postgraduate course for management of innovation and new technologies

\subsection{Productivity}

The overtime monitoring of productivity, based on sectoral and enterprise size, has concluded that subsidized manufacturing SMEs successfully faced the tough competition only the first 3-5 years of their operation beginning. It happened due to generous subsidies which ensured comparatively smaller financial and operating costs than others, established to other Greek regions. In Thrace, five industries have the relatively highest productivity, and hence the greatest international competitiveness, textiles and clothing, packaging materials, processed food and beverages, aluminum products and very smart electronic structures for some niche markets. However, while the production capacity and their size regarding personnel of Thracian companies belonging to these five sectors are the same to the corresponding one's regions of Attica, and Central Macedonia, in average terms, the productivity of Thracian firms stands at slightly lower levels. This phenomenon can be interpreted empirically, e.g. firms of the previous two mentioned regions, use much more effective management, have workers with longer and greater experience, and have better implicit know-how. However, certainly, the content of this interpretation cannot fully explain and evaluate the overtime productivity figures for the industrial system of Thrace. Indeed, in Thrace there is latent smart growth retardation since there is no clear and visible transition, neither to the new knowledge economy due to lack of well-experienced staff to exploit new production technologies, nor transition from the technical to the scientific division of labor, factors that dramatically positive influence the total business productivity (theoretical views of Malecki (1999) and Fadairo and Massard (2002).

\subsection{Internationalization and exports:}

The total exports of Thrace amounted to 8,4\% of its GDP and manufactured products account for $43.2 \%$ of its total exports(The year 2012). Regarding the pure internationalized activities of Thracian firms, they concern only $8,9 \%$ of the total, with the internationalization forms as shown in Table 5:

\section{Table 5 Internationalization forms and types of Thracian firms}

\begin{tabular}{|l|l|}
\hline Internationalization forms & Percentage \% \\
\hline Contractual agreements with domestic exporters/ distributors & 35,0 \\
\hline Contractual agreements with foreign importers/distributors & 16,3 \\
\hline Subcontracting for manufacturing some of the parts of final products & 15,8 \\
\hline Wholly Owned Subsidiaries & 9,4 \\
\hline Foreign Direct Investments & 6,8 \\
\hline Greenfield investments & 5,9 \\
\hline Acquisitions & 3,4 \\
\hline Joint ventures & 2,6 \\
\hline Strategic alliances & 2,4 \\
\hline
\end{tabular}




\begin{tabular}{|l|l|}
\hline Licensing & 1,4 \\
\hline Franchising & 1,0 \\
\hline Total & 100,0 \\
\hline
\end{tabular}

Source: Adhoc field research of Eastern Macedonia and Thrace Institute of Technology (EMATTECH) (EMMATECH 2014)/ Postgraduate course for management of innovation and new technologies

Also, the following information is beneficial regarding the real export activities of Thracian firms. In essence, a $45.4 \%$ of them looked for entirely new markets, without often successful results, a $21.3 \%$ looked for raising low-cost capital to finance their expenses for export processes, a $17.8 \%$ looked to foreign markets for better competitive effectiveness, and a $15.5 \%$ looked for higher quality, and somewhat cheaper materials used in their production process 3.3 Added value, total, domestic and local: The total added value of the industrial sector is $32.3 \%$ in average terms, e.g., it is slightly less of national one $34.8 \%$ and the local stands for $64 \%$ of the total.

\subsection{General liquidity and profitability of firms}

It is considered unsatisfactory for $82 \%$ of firms, for the periods, 1976-1983, 1989-1993, 1998-2001 and 2008-2014. Only 18\% of them can be regarded as relatively well for all period studied. A percentage of $54 \%$ of firms had a moderate to relatively good satisfactory liquidity for the periods 1984-1988 and 1993-1997 and 2002-2007, owing to the transient right economic conditions. Equity financing is generally tricky for three years after the end of generous subsidies.

\subsection{Quality of management, organization and effectiveness of subsidized firms}

Manufacturing companies that exploited in the best way the generous subsidies and they invested them effectively in modern production technologies, management and marketing tools, introduced smart innovations in their production process, amounting to $17,7 \%$ of the total. On a sectoral basis, the industries with the best quality of management, marketing, organization, efficiency, and higher productivity were food, and beverage, electronics /information, Adhoc technological products and aluminium products.

\subsection{Innovations and innovative activities of subsidized firms}

The sectors with the more unusual explicit innovative activities in a hierarchical basis are pharmaceutical, electronic devices and components, auto parts, metal construction, and food and beverages. Accordance field research, done by EMATTECH /REMTH, the clear innovative firms consist of only $12,5 \%$ of total SME's established in Thrace.

3.7 Research and technological cooperation among Democritus University of Thrace (DUTH), Eastern Macedonia and Thrace Institute of Technology (EMATTECH) and manufacturing firms The subsidized firms to be very competitive, will have to base on, new process technologies, automation, knowledge and close research and technological cooperation with DUTH, EMATTECH / REMTH. Unfortunately for many reasons, mainly due to ineffective evaluation system of business plans, submitted by candidate investors. The modern collective tool of the triple helix, as the most effective tool for a smart regional industrial development, was absented in Thrace. This means that there is not any creative cooperation among, public sector, as a great supplier of products/services produced by Thracian firms, DUTH/EMATTECH/REMTH and other institutes and organizations, as producers of new research, patents and technologies and the private sector, as users and producers of previous (theoretical views of Scott and Storper 2003, Morgan and Nauwelaers 2003).

\subsection{Specialized marketing, exports, and innovation and competition strategies}

Specific marketing, exports, innovation and competition strategies, followed by Thracian industries, on a percentage basis and common terms for 17 years, 1992-2008, are given in Table 6.

Table 6: Specific marketing, exports, innovation and competition strategies/practices, followed by Thracian industries, on a percentage basis Specific strategies/practices followed Good Moderate Very small 


\begin{tabular}{|c|c|c|c|}
\hline $\begin{array}{l}\text { Increasing their adaptability, in a qualitative and quantitative } \\
\text { basis, to the changes of global competition }\end{array}$ & 14.5 & 45.2 & 41.3 \\
\hline $\begin{array}{l}\text { Finding new smart practices in response to the saturation of } \\
\text { world markets and increased international competition }\end{array}$ & 9,8 & 34.0 & 56,2 \\
\hline $\begin{array}{l}\text { Configuring a new, more productive, form of organization of } \\
\text { production processes, which respond to the problems of cost } \\
\text { competitiveness, as a result of the emergence of new } \\
\text { competitors, China, etc. }\end{array}$ & 15,8 & 21,1 & 63,1 \\
\hline $\begin{array}{l}\text { Producing higher quality products than existed, able to be } \\
\text { sold to higher prices in mature markets, without losing } \\
\text { market shares }\end{array}$ & 9,3 & 23,2 & 67,5 \\
\hline $\begin{array}{l}\text { Use new flexible production technologies, based on } \\
\text { computerized systems, allowing firms to avoid expensive } \\
\text { malfunctions to be adjusted to dramatic changes of consumers } \\
\text { demands and, at the same time, to be adapted more quickly to } \\
\text { market diversifications and shorter product life cycles. }\end{array}$ & 11,8 & 11,2 & 77,0 \\
\hline $\begin{array}{l}\text { New smart forms of cooperation between enterprises, better } \\
\text { choice of subcontractors and outsourcers. Long-term } \\
\text { contracts with suppliers selected with new criteria, based on } \\
\text { their technological complementarity, while the cost plays a } \\
\text { secondary role. New forms of cooperation emerged, giving } \\
\text { synergies and economies of scale, networks, strategic } \\
\text { alliances, cooperation agreements, coproduction systems, etc. }\end{array}$ & 14,6 & 22,7 & 62,3 \\
\hline $\begin{array}{l}\text { Significant increase in expenditure in research activities and } \\
\text { smart marketing techniques, to cope with the pressures of } \\
\text { competition }\end{array}$ & 17,8 & 43.6 & 38,6 \\
\hline Focused strategy based on the lower cost to all markets & 39,4 & 34,6 & 16,0 \\
\hline $\begin{array}{l}\text { Focused strategy based on the lower cost to certain markets- } \\
\text { niches }\end{array}$ & 27,4 & 32,2 & 40,4 \\
\hline $\begin{array}{l}\text { Focused strategy based on differentiation to certain markets- } \\
\text { niches }\end{array}$ & 14,8 & 26,5 & 58,7 \\
\hline Focused strategy based on differentiation to all markets & 16,4 & 38,0 & 45,6 \\
\hline
\end{tabular}

Source: Adhoc field research of EMATTECH/REMTH 2014/ Postgraduate course for management of innovation and new technologies Greece spent many resources for the development of Thrace through fast industrialization, but the data regarding their competitiveness show that the majority of industrial firms belong to traditional sectors with medium technology in production processes, without innovations, without cost, or operating and quality, competitive advantages (Maskell 2001 and Adhoc field research of EMATTECH/REMTH 2014).

4. Indicative proposals for innovative and coherent regional policies based mainly on smart specialization and flexible industrial strategies

The new economic reality after the 1995-year that globalization intensified due to China and other former communist countries come dynamically into the global financial system- changing the global labour contribution and competition terms. That new economic environment imposes new rules in, competitive spatial advantages, global manufacturing systems, firms' marketing strategies, alliances, collaborations and synergies among giant firms becoming more long-term and deeper, outsourcing practices becoming more sophisticated and mutually profitable, production and service technologies, mainly ITC's, which in turn impose new developmental strategies and policies, etc. 
Any country/region which denies this hard reality means it suffers from myopia approach and remains uncompetitive and underdeveloped. What could say the fact that the new economic conditions after 1995, require new and more sustainable and intelligent spatial development policies for poor regions like Thrace? In general, the new global economic conditions need four basic terms, for an area to compete successfully the hard competition.

a. new entrepreneurial and innovative culture from all stakeholders,

b. less state bureaucracy,

c. the better tax system,

d. smarter infrastructure and better economic and business environment capable of attracting many new FDI's with, optimal size and functionality, modern, cost-effective process technologies, economies of scale to every function and high extroversion.

In the context of the economic developments outlined to previous, can Thrace, that is ranked at the bottom regarding competitiveness among 272 EU regions, to introduce and implement better regional development policies and industrial strategies. The answer is yes, but under, many, specific and strict conditions and strenuous efforts.

All previous mean that Thrace has to shift to an economy with a new structure, new sources which will ensure competitive spatial advantages, modern and brilliant production models characterized by high competitiveness, extroversion, innovative entrepreneurship and digital applications everywhere. In this context, it is given, on an indicative basis, some proposals for a new regional policy based mainly on smart specialization and flexible industrial strategies.

4.1. Firstly and above all, Greece, as an EU member, needs an entirely new innovative development model, which will help it to be much more globally competitive, to be ranked among the 30 more developed economies internationally. This fact itself will help Thrace, which is located to the best geostrategic position of Greece, to upgrade it is competitive and effectiveness of productive systems. It maybe would be the productive bulwark of the country and a smart cooperation platform with the Balkan and Black Sea countries. Also, it would be the spatial pattern of interregional strategic cooperation in, environment protection systems, renewable energy systems, join-research and technology institutions, smart clusters and networks among SME's of Bulgarian and Turkish neighboring regions, etc. achieving development with more depth, producing higher value-added products/services.

4.2. Almost equal to previous, it is needed to be cultivated in Thracian policy-makers and citizens a new way of thinking, regarding innovative entrepreneurship. People from different disciplines have to learn to cooperate creatively and solve severe but effective growth problems. Smart forms of cooperation and synergy will help all stakeholders to improve local production systems, mainly regional SME's competitiveness and exports.

4.3. It has to be ensured that the resources of new ESPA 2014-2010 intended to boost innovative regional development will be enough and sufficient to support all innovative Thracian SMEs dynamically through well-targeted actions. Not many, but few well-selected and viable firms will be helped with resources having an optimal crucial size, to increase their smart global competitiveness. Such actions for firms could be, further upgrading of human resources and production technology, more knowledge produced in the home by firms, new IT infrastructure.

4.4. Decision-makers will have to focus on well-selected and studied production units, supporting only those that will be based their competitiveness solely, on innovations, applied knowledge and high production technologies. It is essential Thrace specialization to be branded for a few production fields that incorporate and related to knowledge, innovation, and intelligence. Even, the marketing niche strategy has to be a strategic goal for middle size innovative firms avoiding the intense direct competition of giants.

4.5. Thrace needs a crucial mass of innovative firms, operating as key-drivers of competitive growth, and it means that it has to become the principal goal of the new development strategy. Prerequisites for that are the close and effective cooperation among firms, DUTH/EMATTECH and government. The triple helix tool can promote and upgrade firms to innovate in a better way and to exploit smartly the knowledge and 
research outputs, produced by local universities and research institutions. The most effective way for Thrace to promote its competitive industrial growth is to be benefited from the knowledge and applied research produced through triple helix cooperation processing, along with the new more intelligence and generous incentives, to provide products with intensive functional, qualitative and technological differentiation, and low cost. For instance, the dominant sectors of, food/beverages, textiles/clothing, pharmaceutical, and car parts to be done the new growth locomotive

4.6. Decision and policymakers and takers have to avoid duplication and copying of smart growth strategies followed by other regions with entirely different economic characteristics and structure. Imitation strategies don't be often efficient and effective. They have to focus on certain and well-designed key development factors capable of supporting brilliant growth strategies, entirely adapted to local economic conditions. Great attention to sectoral/product/services specialization.

4.7. The spatial differentiation of Thrace, as a dynamic production system, has to be very clear to international markets, leading to a self-explanatory, productive brand name. Namely, Thrace has to be repositioned to global markets.

4.8. It has to create powerful intelligence investment incentives and financial mechanisms supporting generously only those industrial SMEs, with innovative activities/functions, to upgrade their in-home ability to produce new applied technologies, or by purchasing, transfer and introduction tailor-made new knowledge and technologies, at an early stage, so that to go ahead successfully their innovative attempts.

4.9. Creation of right institutional conditions enforcing the full participation of interested regional stakeholders to encourage innovation and innovative practices everywhere effectively. Advantageous is the establishment of reliable financial and scientific structures, monitoring and evaluation the suggested industrial innovation policies on an everyday basis. Such a structure could be an innovation observatory managed by the innovation committee.

4.10. Creation and use some intelligent indicators, measuring the contribution of every strategy/policy to growth rates. For example, innovation influence in firms' operational functions likes production cost, product quality, the structure of total operation cost, exports as \% of total sales, etc. Such metric indicators can help policymakers to improve, revise and adapt their regional policies and strategies for smart development, since, whatever can be measured, it can be improved.

4.11. The essential protection of the natural and built environment and natural resources through sustainable production systems and management tools. Such growth can ensure the quality of life and resources efficiency to attract international investors with sensitivities in such matters.

4.12. Smart exploitation of all existed transport and energy infrastructure and networks in order Thrace to have emerged as the best transportation, logistic and energy hub in S.E Europe. Integration of road, rail, airport and seaport infrastructures and networks into trans-European networks. Also, the respective intraregional and interregional infrastructures have to be improved/upgraded to reduce operational costs. The promotion of combined transport infrastructures has to be reengineered and updated so that to be linked much more electively with the corresponded European ones.

4.13. Finally, the new development plan 2016-2021 will have to form a very favorable business environment, capable of attracting excellent and significant investments with excellent global competitive. The new investment law has to offer only smart operational incentives- lower tax rates, higher depreciation rates, more accessible access to bank loans, lower financial costs, more generous but very smart incentives for startups, spin-offs, spin-outs, and innovative enterprises (Adhoc field research of EMATTECH/REMTH 2014).

\section{Indicative proposals for suitable investments in Thrace, in sectoral, industry and product level}

We give some indicative investment ideas, ideal for Thrace, in order decision-makers to prepare ad-hoc investment dossiers aiming to present to international business forums, or showrooms: 5.1. Agro foods sector for specialized food/beverages, fresh and processed

i. $\quad$ Production of functional, antidiabetic and unique baby foods

ii. New kind of pastries, organic, traditional with organic vegetables, etc. 
iii. Frozen organic vegetables and fruits

iv. Canned organic vegetables in aseptic and attractive packaging, without preservatives, with spicy flavors, primarily for export.

v. Installations for selection and packaging organic fresh fruit and vegetables

vi. Wines and grape juices, local beers with extra tastes, organic mountain teas

vii. Organic livestock products, milk, cheese, yoghurt, meat, sausage

5.2. Specialized medical and textiles from organic and colored cotton via smart processing, based on knowledge- and nanotechnology.

i. Fashion garments from organic cotton.

ii. Fabrics unburned and waterproofing for particular purposes, clothing, balloons, parachutes, firefighters, sailcloth, pilots, etc.

iii. Exclusive cotton products for medical and cosmetic uses after nanotechnology processing.

5.3. Investments to wood-process units for technological modernizations and production of new, more complex products and to exploit the significant zeolite.

I. Wood processing plants to produce new, more complex products for attractive and safe packaging.

II.The exploitation of zeolite deposits and production of various products for agriculture and medical uses.

5.4. Investments for intelligence product extensions and modernizations of existing manufacturing units and new investments on new smart packaging materials and environmental products.

I. Special incentives for significant investments to firms producing high-tech products, microelectronics, biomedical devices, etc.

II. Special incentives for substantial investments to firms producing any kind of packaging materials for export.

III.Special incentives for significant investments to firms providing renewable systems, systems for environmental protection, either some components or turn-key systems.

5.5. Investments to intelligence services and alternative tourism

I. Investments on smart logistic centers, offering very high value-added services, in Alexandroupolis and Kavala.

II. Alternative tourism, medical, congress, religious, mountain, ecological, etc.

III. Marinas and extreme sea sport tourism. (Stathakis 2013)

6. Attracting FDIs in Thrace-Foreign Direct Investments and an econometric approach to analyze the factors influencing the FDIs' attraction in Thrace

Fast-growing regions and countries are associated with higher FDI inflows. The literature generally captures these growth characteristics by using total GDP, GDP per capita, GDP growth rates as \%, or at sectoral or firm-level measuring their competitiveness in terms of industry or firm output. The initial and potential future demand conditions in a regional market act as a signal to inward investors on the attractiveness of a location. Furthermore, it allows investors to locate where they can take advantage of the business environment and scale economies.

Host countries or regions have open economies without technical or commercial barriers are widely considered to be positively related to attracting FDI. Thrace, although have many comparative advantages and could be benefited from being in the European Union, and therefore part of the single market, unfortunately, it was benefitted very little because it couldn't upgrade them in competitive advantages.

To study the factors influencing the FDIs' attractiveness of Thrace, we based on an econometric model approachable to reveal the sensitivity of outcomes in the underlying model. The research methodology based 
on ad-hoc panel data technique having advantages over cross-sections and in time series (Fernandez-Val 2007). The model chosen is the Ordinary Least Squares.

The model's specification is a. it based on the literature review and past studies, b. is a model that consisted of by macroeconomic factors and each factor influences the attractiveness of foreign direct investment, $c$. model's equations run on STATA to explore the influencing four factors that affect foreign direct investments in terms of integrated and discrete analysis.

The model's formula is:

\section{FDIit $=\alpha 0+\alpha 1$ GDPit $+\alpha 2$ RDit $+\alpha 3$ MPIit $+\alpha 4$ TIit + eit}

$\alpha 0=$ Intercept,$\alpha 1$ : coefficient of GDP,$\alpha 2=$ coefficient of R\&D, $\alpha 3=$ coefficient of Manufacturers Production Index (MPI), $\alpha 4:=$ coefficient of Trade Index (TI), $\varepsilon=$ error term and FDIi presents the inflow of foreign direct investment of I'-the period in year t. To run the model, we used the data in time series form in the table below.

Table 7: Data used by our model in timeseries form

\begin{tabular}{|l|l|l|l|l|l|}
\hline Year & $\begin{array}{l}\text { RGDP in a } \\
\text { million } \\
\text { reference } \\
\text { year 2005 }\end{array}$ & $\begin{array}{l}\text { FDIs } \\
\text { inflows } \\
\text { reference } \\
\text { the year } \\
\mathbf{2 0 0 5}\end{array}$ & $\begin{array}{l}\text { Gross investments } \\
\text { in R\&D as \% of } \\
\text { RGDP reference } \\
\text { year 2005 }\end{array}$ & $\begin{array}{l}\text { Manufactures } \\
\text { production } \\
\text { index } \\
\mathbf{2 0 0 2 = 1 0 0 ~ M I ~}\end{array}$ & $\begin{array}{l}\text { Trade index as } \\
\text { \%f RGDP } \\
\text { imports } \\
\text { +exports) TI }\end{array}$ \\
\hline Variables & GDP & FDI & R\&D & MI & TI \\
\hline 2002 & 4.014 & 4,1 & 0,38 & 100,0 & 31,4 \\
\hline 2003 & 4.135 & 3,8 & 0,37 & 101,2 & 32,7 \\
\hline 2004 & 4.224 & 2,9 & 0,36 & 101,6 & 34,8 \\
\hline 2005 & 4.428 & 4,8 & 0,38 & 100,0 & 34,1 \\
\hline 2006 & 4.456 & 6,5 & 0,38 & 99,2 & 35,2 \\
\hline 2007 & 4.526 & 1,3 & 0,35 & 98,8 & 35,6 \\
\hline 2008 & 4.653 & 0,8 & 0,37 & 97,6 & 34,3 \\
\hline 2009 & 4.348 & 0,6 & 0,36 & 90,3 & 31,2 \\
\hline 2010 & 4.130 & -- & 0,35 & 87,3 & 29,5 \\
\hline 2011 & 3.902 & -- & 0,34 & 82,4 & 29,7 \\
\hline 2012 & 3.675 & -- & 0,33 & 80,1 & 32,2 \\
\hline 2013 & 3.455 & 1,7 & 0,35 & 76,8 & 34,2 \\
\hline 2014 & 3.456 & 2,8 & 0,39 & 75,7 & 36,5 \\
\hline 2015 & 3.286 & 2,1 & 0,36 & 74,2 & 35,4 \\
\hline
\end{tabular}

Source: HELSTAT annual reports 2003-2016, www.economics.gr, IOBE 2018, KEPE 2019, Invest in Greece reports, and interventions, adaptations and compilation of data by authors

The empirical result is presented to the next table 8, displaying the regression results regarding our data set. The study conducted on standardized panel evaluation techniques of OLS (ordinary least square), fixed effect and random effect. To choose the specific model, we carried out the Breusch-Pagan Lagrange multiplier test (1980) and the Hausman test. Firstly, the Breusch-Pagan Lagrange Multiplier test performed to reject the pooled OLS model over the random effect model based on the outcomes.

Table 8: Pooled OLS Regression Results 


\begin{tabular}{|l|l|l|l|l|}
\hline Independent variables & Coefficient & $\begin{array}{l}\text { Standard } \\
\text { error }\end{array}$ & t-statistics & P-values \\
\hline Log R- GDP & $\mathbf{0 , 1 6 7 0}$ & $\mathbf{0 , 3 4 5 6}$ & $\mathbf{0 , 1 8 3 4}$ & $\mathbf{0 , 8 6 4 0}$ \\
\hline R\&D & $\mathbf{0 , 1 7 4 0}$ & $\mathbf{0 , 3 0 2 0}$ & $\mathbf{0 , 1 7 8 7}$ & $\mathbf{0 , 8 7 4 5}$ \\
\hline MPI & $\mathbf{0 , 1 6 3 0}$ & $\mathbf{0 , 2 9 8 0}$ & $\mathbf{0 , 1 6 8 0}$ & $\mathbf{0 , 8 4 5 0}$ \\
\hline TI & $\mathbf{0 , 0 7 4 5}$ & $\mathbf{0 , 0 0 3 1}$ & $\mathbf{1 7 , 5 4 5 0}$ & $\mathbf{0 , 0 0 0 0}$ \\
\hline Constant & $\mathbf{3 , 5 1 3 4}$ & $\mathbf{7 , 1 3 5 6}$ & $\mathbf{0 , 4 3 5 0}$ & $\mathbf{0 , 6 5 7 4}$ \\
\hline Summarizing model & & & \\
\hline \multicolumn{1}{|c|}{$R^{2}$} & $\mathbf{0 , 7 8 3 4}$ & $\mathbf{0 , 7 7 9 0}$ & \\
\hline Adjusted $R^{2}$ & $\mathbf{0 , 0 0 0 0}$ & & \\
\hline Probability of F-statistics & &
\end{tabular}

a. The heteroscedasticity test gives the results according to Breusch-Pagan employed to test:

Null Hypothesis Ho: There is not any heteroscedasticity in the data

Alternative Hypothesis Ha: There is heteroscedasticity in the data

The probability value of the test is 0.00 . Therefore, Ha is accepted and rejected the null hypothesis. Heteroscedasticity is a difficulty because OLS regression supposes that residuals are taken from data that has constant variance. It also causes of biased results and estimation.

\section{b. Hausman test gives the results:}

Null Hypothesis Ho: Random effect model is appropriate

Alternative Hypothesis Ha: Fixed effect model is appropriate

The study rejects the null hypothesis in favour of the fixed-effect model.

From the above table and after the regression analysis employed to determine the relationship among FDI attracted in Thrace and four factors, GDP growth rate, R\&D investments as \% of RGDP, Manufacturing Production Index MPI and Trade Index TI that influence the FDI attractiveness we result that the inflow of quantity FDI influenced by, the TI 45,4\%, the MPI $28,7 \%$, the R\&D 16,9\% and the R-GDP growth rate $9,0 \%$.

\section{Conclusions}

To this paper was tried to be described the ineffective and wasteful regional development and industrial policies, followed by decision-makers and takers the last 40 years, 1976-2015, for the Greek most impoverished region of Thrace. We highlighted all disadvantages and counter-incentives, in quantitative, qualitative and systemic basis. We criticized in-depth, the overtime designed and implemented inefficient, not innovative, regional economic and industrial policies and strategies.

Although the main manifest goal of all local plans for the most impoverished region was its faster growth rates-greater than the national average growth rate, to reach the other Greek areas socioeconomically, the final results were below the expected ones. Instead of Thrace to be emerged as the leader region of SE Balkans because of generous incentives/artificial cost competitive advantages and its geographical and geostrategic position, even today it remains the most impoverished region among the 13 Greeks ones and it is ranked at 263 order, among 272 EU regions.

Yet, it is highlighted the fact that the developing of Thrace couldn't be based anymore on wasteful and ineffective generous financial incentives but smart, flexible and well-specialized growth strategies and policies. It is needed to be offered to candidate investors, mainly FDI's, some unique and well-documented business tools boosting the total competitiveness, beyond whatever generous financial and tax incentives. It was over-timely proved that, neither the capital resources which were spent wastefully as subsidies- without any well structured and focused growth strategy nor the low total labour cost, since a $12 \%$ subsidized it was 
capable of supporting effectively Thracian productive system to gain real, sustainable and long-term competitiveness. We proved, through well-documented data/information that, every developmental approach, based only on abundance and generous financial incentives-without the existence of right business environments such as strong TI, MPI and R\&D indices- it is not adequate. Sustainable development needs much more, and smart motives and incentives, excellent analysis of present situation through tools like, PEST, SWOT and benchmarking analysis and then, very well-designed and focused regional development policies based on smart/intelligent strategies-flexible specialization, open local/global applied knowledge exploitation, innovations and intelligent alliances and cooperation with research centers. All those are the factors leading to a real regional competitive development based on intelligent FDIs. The continuous reference of decision-makers / takers to its comparative advantages, not too competitive ones-without any systematic approach to growth goals, weren't enough to support the real capabilities of the region. Through simple cost/benefit analysis proved that, the socioeconomic cost of all previous regional development policies were overtime much greater to public benefits. Instead of valuable state resources to be focused only to few dynamic, with optimal average size, with valuable economies of scale to every function, with great extroversive new investments, they unfortunately led to many small and disputable viability investments, having very small positive outcomes and growth leverage.

In practical level, the business plans, submitted by new investors to responsible services /taskforces, for evaluation, were unexpected simple, shallow, without valuable data that could document their viability and despite of that were approved and subsidized by the responsible regional services . Even, the majority of them didn't implement entirely the designed and approved business plans and so that, there was a wasteful of the scarce and valuable state resources. The percentage of implementation of new investments approved by the adhoc services, never overcame the 35\%. All that explains why Thrace needs new, very smart and wellspecialized and very intelligent development policies/strategies.

Take in account all the previous, it was considered useful and we presented to this paper some new and innovative indicative proposes for the next programming period 2021-2027, based on the international experience and good practices, but well-adapted to Thracian socioeconomic conditions. We suggested, essentially, a new growth model for the today position of Thracian economy that will be, sustainable, realistic, well-focused to few certain sectors and industries and will exploit its hidden, or evident competitive and dynamic advantages.

\section{References}

[1.] Academy of Athens (1994), "The development of Thrace" a book published by Academy of Athens.

[2.] Akalpler E, Adil H (2017) "The Impact of Foreign Direct Investment on Economic Growth in Singapore between 1980 and 2014”. Eurasia Business and Economics Society Springer, pp 1-16

[3.] Carmona M, Burgess R, and Bedenhorst M.S (2009) "Planning thorough projects- Moving from master planning to strategic planning - 30 cities", book ISBN: 978-90-8594-023-4, www.technepress.nl

[4.] Cooke P, Morgan K (1998), "The Associational Economy, Firms, Regions, and Innovation", Oxford University Press

[5.] Cooke P (2001) "Regional systems of innovation" Industrial and Corporate Change, Vol. 4. No 4.

[6.] Cortright J (2001), "New growth theory, technology and learning" Reviews of Economic Development Literature and Practice No 4. US Economic Development Administration.

[7.] EMATTECH (2014), Adhoc field research by postgraduate students of the course: "Management of Innovation and New Technologies", Greek International University/ Kavala.

[8.] Esteban JM (2000), "Regional convergence in Europe and the industry mix", Regional Science and Urban Economics, vol. 30, pp. 353-364

[9.] European Commission (2004)," A new partnership for cohesion", Luxemburg: Office of official Publication of the E.U.

[10.] Fadairo M, Massard N (2002), "The Geography of Innovation: Challenges to Technology Policy within Regions", 6th Annual Conference of European Network on Industrial Policy (EUNIP), Turku Finland.

[11.] Fernandez-Val I (2007), "Fixed Effects Estimation of Structural Parameters and Marginal Effects in Panel Probit Models," paper, mimeo, Boston University Department of Economics. 
[12.] Hurst C, Thisse JF, Vanhoudt P (2000), "What diagnosis for Europe's ailing regions?" European Investment Bank Papers vol. 5(1), pp. 9-29

[13.] Hellenic Statistical Authority - HELSTAT (1985-2019), various overtime publications, Athens.

[14.] Jackson M, Petrakos G (2001), " Industrial Performance under Transition: The Impact of Structure and Geography. The Development of the Balkan Region", Aldershot: Ashgate, pp 141-174.

[15.] Knorringa P, Meyer-Starmer J (1998), "New Dimensions in Local Enterprises Co-operation and Development: from clusters to industrial districts" in ATAS Bulletin XI-New approaches to science and technology co-operation and capacity building- The Hague and Duisburg

[16.] Krugman P, Venables A (1995), "Globalization and the Inequality of Nations", The Quarterly Journal of Economics, Vol. CX, Issue 4, pp 857- 880.

[17.] Krugman P (1998) "What's new about the New Economic Geography?" Oxford Review of Economic Policy, Vol.14, No.2, pp 7-17.

[18.] Lamprianidis L (1989), "Regional Development Incentives for industry-Critical Review". Technical Journal, 9 (2), all pages, Athens.

[19.] Lucas R (1988), "On the mechanics of economic development", Journal of Monetary Economics, volume 22 /3-42, North-Hall.

[20.] Malecki EJ (1999), "Knowledge and regional competitiveness", Paper presented at the International Symposium Knowledge, Education and Space, Heidelberg/Germany.

[21.] Maskell P (2001), "Future Challenges and Institutional Preconditions for Regional Development Policy" in Feldman M. \& Massard N, Institution and Systems in the Geography of Innovation, Kluwer Academic Publishers, Boston, Dordrecht, London.

[22.] Morgan K and Nauwelaers C (2003), "A regional perspective on innovation: from theory to strategy -The Challenge for Less-Favored Regions" in Regional Innovation Strategies, Routledge, London.

[23.] McKiernan N (1992) "Strategies of Growth: Maturity, Recovery and Internationalization", Rutledge Series in Analytical Management, pp. 49-80.

[24.] Mourmouris I (1997), "Industrial Development of Thrace" TEE, monograph published in Official Quarterly Magazine of TEE "Technika Chronika" TEE /branch of Thrace, Komotini.

[25.] Organisation for Economic Co-operation and Development (OECD) (2019), "Making Decentralization Work". A Handbook for Policy Makers. Paris 2019

[26.] Polyzos S (1997), "Empirical Investigation of Factors Affecting Decisions of Enterprises' Installation Area", Series of Research Papers, University of Thessaly.

[27.] Romer PM (1990) "Endogenous Technological Change", the Journal of Political Economy Vol. 98, No. 5, Part 2: The Problem of Development: A Conference of the Institute for the Study of Free Enterprise Systems, pp 71-102.

[28.] Rehman HU (2016) "Comparative Analysis of the Socioeconomic Determinants of Foreign Direct Investment: Evidence from Pakistan”, Pakistan Economic and Social Review 54, pp 255-274.

[29.] Scott AJ, Stopper M (2003), "Regions, Globalization, Development" in Regional Studies, vol 37 , 6\&7, pp 579- 593.

[30.] Stathakis E (2013), "The EU resources and the lost developmental opportunities for Greece, and the region of EMTH", Article published in the local newspaper Paratiritis-Observer/ Komotini/Greece

[31.] Stathakis E, Bandekas D (2018), “Thrace 1975-2014: 40 years of ineffective policies of regional sustainable development", book editor Paratiritis, 2018 Greece

[32.] Tampakoudis I, Subeniotis D, Kroustalis I, Skouloudakis M (2017), "Determinants of Foreign Direct Investment in Middle-Income Countries: New Middle-Income Trap Evidence" Mediterranean Journal of Social Sciences 8, pp 58-70.

[33.] Todtling F, Trippl M (2005), "One size fits all? Towards a differentiated regional innovation policy approach” Magazine Research Policy 2005/34

[34.] Yu J, Jackson R (2011), "Regional Innovation Clusters: A Critical Review” Growth and Change Magazine, 2011/42(2)

[35.] Wessner CW (2005), "Entrepreneurship and the innovation ecosystem", In Audretsch DB, Grimm H, Wessner CW, editors, New York, Springer, 2005 